\title{
eCommons@AKU
}

March 2005

\section{Teachers' perceptions of their professionalism in government primary schools in Karachi, Pakistan}

Meher Rizvi

Aga Khan University, meher.rizvi@aku.edu

Bob Elliot

Queensland University of Technology, Australia

Follow this and additional works at: http://ecommons.aku.edu/pakistan_ied_pdck

Part of the Educational Administration and Supervision Commons, and the Elementary Education and Teaching Commons

\section{Recommended Citation}

Rizvi, M., \& Elliota, B. (2005). Teachers' perceptions of their professionalism in government primary schools in Karachi, Pakistan. Asia-Pacific Journal of Teacher Education, 33(1), 35-52. 
This article was downloaded by: [INASP - Pakistan (PERI)]

On: 17 October 2012, At: 05: 57

Publisher: Routledge

Informa Ltd Registered in England and Wales Registered Number: 1072954 Registered

office: Mortimer House, 37-41 Mortimer Street, London W1T 3J H, UK

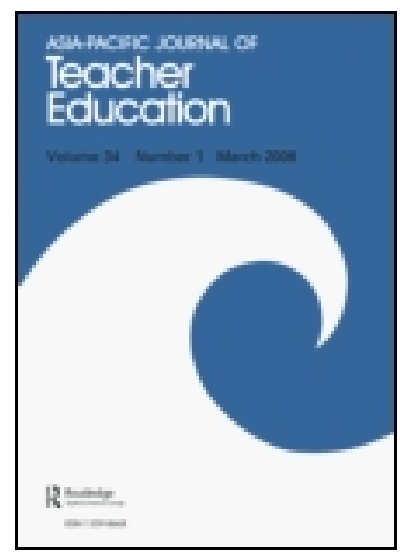

\section{Asia-Pacific J ournal of Teacher Education}

Publication details, including instructions for authors and subscription information:

http:// www.tandfonline.com/loi/ capj 20

\section{Teachers' perceptions of their professionalism in government primary schools in Karachi, Pakistan}

Meher Rizvi Corresponding author ${ }^{\mathrm{a}} \&$ Bob Elliot ${ }^{\mathrm{a}}$

${ }^{a}$ Queensland University of Technology, Australia

Version of record first published: 19 Oct 2010.

To cite this article: Meher Rizvi Corresponding author \& Bob Elliot (2005): Teachers' perceptions of their professionalism in government primary schools in Karachi, Pakistan, Asia-Pacific J ournal of Teacher Education, 33:1, 35-52

To link to this article: http:// dx.doi.org/ 10.1080/ 1359866052000341115

\section{PLEASE SCROLL DOWN FOR ARTICLE}

Full terms and conditions of use: http://www.tandfonline.com/page/terms-andconditions

This article may be used for research, teaching, and private study purposes. Any substantial or systematic reproduction, redistribution, reselling, loan, sub-licensing, systematic supply, or distribution in any form to anyone is expressly forbidden.

The publisher does not give any warranty express or implied or make any representation that the contents will be complete or accurate or up to date. The accuracy of any instructions, formulae, and drug doses should be independently verified with primary sources. The publisher shall not be liable for any loss, actions, claims, proceedings, demand, or costs or damages whatsoever or howsoever caused arising directly or indirectly in connection with or arising out of the use of this material. 


\title{
Teachers' perceptions of their professionalism in government primary schools in Karachi, Pakistan
}

\author{
Meher Rizvi ${ }^{\star}$ and Bob Elliot \\ Queensland University of Technology, Australia
}

\begin{abstract}
This paper examines teachers' perceptions of their professionalism under conditions of educational reforms in government primary schools in Karachi, Pakistan. Conceiving teacher professionalism in terms of four dimensions (teacher efficacy, teacher practice, teacher leadership and teacher collaboration) it reports a quantitative survey research study of teachers in these schools, where educational reforms have been initiated. One conclusion from the study is that such teachers do perceive themselves as professionals - a finding that is counter to the often-held beliefs about these teachers. The paper argues that it is important to regard teachers as professionals, capable of further enhancing their own professionalism, for improvement in the quality of teaching and learning in the government primary schools in Karachi.
\end{abstract}

\section{Introduction}

A central dilemma facing Pakistan's education system is that while government primary schools in Pakistan are characterized by large numbers of under-educated, under-trained, underpaid and, most important of all, undervalued government primary school teachers (Shaikh, 1997; Hoodbhoy, 1998), the future of the country depends on enlightened and informed citizens. In order to address this dilemma, initiatives have been taken at the government, the non-government and the private sector levels to restructure and reform government primary schools in Pakistan.

This paper reports on the findings of a quantitative research project, seeking to understand concepts of teacher professionalism within the government primary schools in Karachi where four initiatives to reform schools have occurred. Based on theoretical literature and a document analysis of the educational reform initiatives in Karachi, teacher professionalism was conceptualized in terms of the four dimensions, namely teacher efficacy, teacher practice, teacher collaboration and teacher leadership.

\footnotetext{
${ }^{\star}$ Corresponding author. The Aga Khan University, IED-PDC, 1-5/B-VII, F. B. Area, Karimabad, Karachi 75950, Pakistan. Email: meher5@hotmail.com
} 
A questionnaire seeking teachers' perceptions of their professionalism was distributed to 550 government primary school teachers in Karachi. It asked the teachers to respond to a range of questions about the four dimensions of teacher professionalism.

As background to the study, information about government primary schools in Karachi and the quality of teaching in these schools is provided. The four reform initiatives and concepts of teacher professionalism are discussed. The second part of the paper reports on the findings from a survey regarding teachers' views of their professionalism in these schools. In, conclusion, it is argued that these findings can be used as the basis of further reform initiatives.

\section{Background to the study}

To place the study in context, we provide an overview of education in Pakistan from 1947 till now, a brief account of the government primary school teachers in Karachi, and the initiatives that have been taken to reform these schools. This section of the paper also outlines the objectives of the research.

\section{Overview of education in Pakistan}

At the time of independence, in 1947, the nation's political leaders had clearly recognized Pakistan's educational problems and had suggested a thorough overhaul of the system. Jinnah, the founder of Pakistan, showed keen interest in shifting the emphasis of education from colonial-administrative objectives to a professionaltechnical bias suited to the needs of a non-dependent, progressive economy (Jalil, 1998).

Quantitatively, Pakistan's education system has shown significant progress. In 1947-1948, Pakistan's entire educational infrastructure was estimated to comprise around 10,000 primary and middle schools, about 408 secondary schools, 46 secondary vocational institutions, 40 Arts and Science colleges, and two universities. There was not a single professional college in the country (Jalil, 1998). According to the Internet Wing Ministry of Information, Government of Pakistan (2000), Pakistan now has 150,963 primary schools, 14,595 middle schools, 9,808 high schools, 708 Arts and Science colleges, 161 professional colleges and 35 universities.

Pakistan's citizens are proud of what they have achieved in terms of quantitative development in education in the past 55 years, but many are apprehensive because Pakistan's literacy rate is still quite low at 39\% (Internet Wing Ministry of Information, Government of Pakistan, 2000). The Ministry of Education (1998) reports that about $25 \%$ of the children in Pakistan are not enrolled in primary schools, and $50 \%$ of those who are enrolled drop out before completing primary schools.

\section{Government primary school teachers and the focus of the study}

Unfortunately, teachers in many government primary schools in Pakistan are still struggling alone in their classrooms to cover content with large groups of learners, 
with few textbooks or resources to help them, and with little reward or recognition. Teaching and learning is pursued with reference to the necessities of classroom control, and teachers' success and survival depends on their ability to balance the two (Hargreaves, 1997). A large number of teachers are in what Hargreaves (1997) calls the pre-professional stage of teacher development, while the education systems in most parts of the world are moving towards what Hargreaves (1997) describes as post-professionalism.

Teachers are probably teaching in the manner that they themselves were taught. Such an assumption requires investigation to how teachers in the government primary schools in Karachi are being helped to learn new ways of teaching and what perceptions of professionalism they hold as a result of the reform initiatives. Specifically, the research reported here sought to identify and analyze the changes that have taken place in the teachers' perceptions of professionalism as a result of reform initiatives and characterize them in terms of the dimensions identified from the literature.

\section{New directions in school reform in Karachi}

There are reasons to believe that the education system in Karachi has progressed. The first reason is that most of the published literature about the quality of education in Pakistan dates back almost seven or eight years and does not present an adequate account of current developments. The research by UNESCO (1994), IDCA (1986) and the BRIDGES Project (Warwick \& Fernando, 1995) are more than nine years old. Secondly, representatives from several non-government organizations (NGOs), private organizations and government organizations in Karachi have personally reported to one of the authors of this paper that various school improvement programmes have begun at the primary school level. Since these programs are fairly recent, most of their findings have not been documented for public access.

What teachers do in classrooms and schools around the world has been undergoing significant change over the last two decades and therefore, any debate about the meaning of teacher professionalism must take place within the context of changing work practices and educational policies. Researchers (Broudy, 1988; Farr \& Middlebrooks, 1990; Willis \& Tosti-Vasay, 1990; Eraut, 1994) have also theorized that professional learning is influenced by: (1) the context in which the learning occurs; (2) factors that motivate individual engagement in learning activities; and (3) the use of knowledge in practice (Scribener, 1998). It is for this reason that we consider it best to identify the different measures that have been undertaken at the government and at the non-government level to reform government primary schools in Karachi. The meanings of teacher professionalism can only be understood in the light of these reforms and new work practices.

In the past ten years, some initiatives have been taken to reform government primary schools in Karachi. A brief summary of four such reform initiatives is now reported.

- Whole school development was the focus of the Primary education programme (PEP). It aimed to involve decision-makers, principals, teachers, parents and the community in improving and sustaining quality primary education. The PEP 
focused on government schools in selected urban settings. PEP was initiated and organized by Teachers' Resource Centre (TRC) in July 1997 and it was completed in 2002 (Teachers' Resource Centre, 1999). TRC is a non-profit, nongovernment organization.

- An education foundation (SEF), which is semi-government organization, initiated Adopt a school program in 1997 for improving the quality of education in government schools; for systematic and replicable collaboration between the private and public sector; and for mobilizing parents and communities in order to sustain the program (Sindh Education Foundation, 1998).

- Book Group, which is a private book publishing organization, initiated the Government school project. In April 1995, the Government of Sindh issued a notification to transfer the management of a government girls' primary school to the Book Group. Since September 1995, the Book Group has been working to improve the quality of education in the school by introducing more relevant curriculum in the school (The Book Group, 1996).

- The Department of Education, Government of Sindh had been engaged since 1991, in a large-scale program called the Sindh primary education development program (SPEDP). The main goals of SPEDP were to improve access to primary education, especially for girls, with equity and quality. SPEDP was completed in 2001 (Bureau of Curriculum and Extension Wing, 1997).

The above mentioned reform initiatives clearly illustrate the focus on increasing access to primary education by restructuring schools and also by improving the quality of education. All of these reforms aimed at maximizing the role of school community and reinvigorating school management.

\section{The dimensions of teacher professionalism}

There exists a large body of literature about the evolving nature of professional work (Rosenholtz, 1989; Hargreaves \& Fullan, 1992; Lieberman, 1992; Sergiovanni, 1994; Shacklock, 1994; Darling-Hammond, 1995; Gusky \& Huberman, 1995; Beck \& Murphy, 1996; McLaughlin \& Oberman, 1996; Day, 1999; Elliott, 2000). This literature indicates that there are different concepts of teacher professionalism. These tend to focus on commitment, satisfaction, efficacy (Beck \& Murphy, 1996) specialized knowledge and expertise, and ethical codes and conduct (Eraut, 1994), discretionary judgement, engagement with curriculum and assessment matters, collaboration with colleagues, sharing power with students and other stakeholders in their education, care for students, continuous learning, autonomy and professional judgement (Hargreaves \& Fullan, 1998).

However, a consideration of the contextual background literature regarding the government primary education system in Pakistan in general, and Karachi in particular, and a comprehensive document analysis of the four reform initiatives pointed towards the following dimensions of professionalism as being important for an investigation into teacher professionalism in that country. 
1. Teacher efficacy.

2. Teacher practice.

3. Teacher collaboration.

4. Teacher leadership.

The first dimension is based on the belief that teachers are more likely to adopt and implement new classroom strategies if they have confidence in their own ability to control their classrooms and affect student learning (Scribner, 1998). Furthermore, Smylie (1988) suggests that teacher efficacy, specifically Personal teaching efficacy (PTE), may act as a professional filter through which new ideas and innovations must pass before teachers internalize them and change their behaviour.

The second dimension refers to actual teacher practice in schools. Schools where teachers continue to believe teaching is basically easy, where the pre-professional view persists, are schools that Rosenholtz (1989) has described as learningimpoverished. They achieve poorer results in basic skill achievement than their more professionally oriented counterparts. Educational reforms would require changes in the way education is generally practiced in government primary schools in Karachi. It would require teachers not only to teach according to the new standards, but also to learn how to teach in ways most of them have never taught before. The success of school reforms would depend on improved teacher practice. As Fullan (1982) argues, educational change depends on what teachers think and do-it is as simple and as complex as that.

The third dimension refers to the ways teachers collaborate with one another professionally. In schools where teachers continue to believe teaching is basically easy, professional learning for new teachers is largely seen as apprenticing oneself as a novice to someone who was skilled and experienced in the craft (Hargreaves, 1997). Once the unquestioned grammar of teaching is passed on from experienced teachers to novices, teachers move to their own separate, and rather isolated classes. On the other hand, a model based on collegial professionalism helps teachers to cope with uncertainty and complexity, respond effectively to rapid change, create a climate which values risk taking and continuous improvement, develop stronger sense of teacher efficacy, and create ongoing professional learning cultures for improved teacher practice (Hargreaves, 1997).

With reference to the fourth dimension, advocates of professional learning communities (Whitbey, 1995; Duignan, 1996; Bhindi \& Duignan, 1997; Sergiovanni, 1998) suggest that teacher leadership surfaces as an important element in addressing school improvement. In such communities teachers assume both formal and informal roles while maintaining direct contact with the classroom. Teacher leaders undertake initiatives to encourage more effective learning and teaching (Macpherson et al., 1999). They are problem solvers, staff developers and powerful influences in their work with colleagues (Moller et al., 2000). Teachers who are leaders lead within and beyond the classroom, influence others toward improved educational practice, and identify with and contribute to a community of leaders (Katzenmeyer \& Moller, 1996). 


\section{Research methodology}

A questionnaire was designed to gather data in relation to each of these four dimensions. This section of the paper describes the questionnaire and reports on the procedures employed to collect and analyze these data.

\section{Description of the questionnaire}

A descriptive questionnaire was used in this research because it aimed to estimate as precisely as possible the nature of the existence conditions, or the attributes of a population (Burns, 2000); for example, its demographic composition, its attitude to the different dimensions of professionalism and the professional development practices.

Using information from literature (Bell, 1993; Bouma, 1996; Gay, 1996; Burns, 2000), personal experience, the concepts noted in the research framework, and the document analysis relating to the schools, the questionnaire was designed to explore the dimensions of professionalism using four Likert scales.

- Scale 1, to investigate teacher efficacy, consisted of 15 items. These items were either drawn from other studies (Bandura, 1982, 1995; Gibson \& Dembo, 1984; Web \& Ashton, 1987; Riggs \& Enochs, 1990; Hoy \& Woolfolk, 1993; Gusky \& Passaro, 1994; Chester \& Beaudin, 1996; Scribener, 1998; Tschannen-Moran et al., 1998) and were modified on the basis of the review of the document of school reform in Karachi.

- Scale 2, containing 15 items, was developed to measure teacher practice. This scale was conceptualized considering several studies (Slavin, 1991; Hargreaves \& Fullan, 1992; Reaves \& Griffith, 1992; Cole \& Chan, 1994; Shacklock, 1994; Darling-Hammond, 1995; Wilson \& Cameron, 1996; Hargreaves, 1997; Ingvarson, 1997; Day, 1999; Campbell, 2000), document analysis of educational reforms in Karachi, and a quantitative study of one of the authors (Rizvi, 1999) on the factors that contribute toward effective teaching in Karachi.

- Scale 3, to measure teacher collaboration, contained 15 items. It was conceptualized considering various studies (Rosenholtz, 1989; Hoy et al., 1991; Reaves \& Griffith, 1992; Chester \& Beaudin, 1996; Katzenmeyer \& Moller, 1996; Fullan, 1997; Hargreaves, 1997; Klecker \& Loadman, 1998; Scribener, 1998; Day, 1999) and the analysis of the educational reforms in Pakistan.

- Scale 4 was developed to measure teacher leadership. It also contained 15 items. These items were conceptualized considering several studies (Cooper \& Conley, 1991; Hoy et al., 1991; Reaves \& Griffith, 1992; Hart, 1995; Smylie, 1995; Wallace \& Hellen, 1995; Chester \& Beaudin, 1996; Katzenmeyer \& Moller, 1996; Klecker \& Loadman, 1996) and the analysis of the educational reforms in Pakistan.

\section{Data collection}

The questionnaire was distributed to 550 government primary school teachers in Karachi. The instrument was translated into Urdu-Pakistan's National language. 
Four hundred and fifty teachers from 35 schools in Karachi, where school reforms had been initiated, responded to the questionnaire.

\section{Data analysis}

Teachers' responses on the 5-point Likert scales were converted into a numerical scale. The numerical value assigned to each response is given below:

Strongly agree Agree Uncertain Disagree Strongly disagree

$\begin{array}{lllll}5 & 4 & 3 & 2 & 1\end{array}$

The frequency distribution of each variable was calculated, as well as the mean score and the standard deviation using the SPSS. The 15 items on the four scales were then factor analyzed to determine underlying patterns (Cohen et al., 2000) and to group the variables that are moderately or highly correlated with each other together (Burns, 2000). Principal Components Analysis (PCA) with varimax rotation was used to extract factors.

Prior to performing PCA the suitability of data for factor analysis was assessed. Inspection of the correlation matrix for the four dimensions revealed the presence of many coefficients of 0.3 and above. The Kaiser-Meyer-Olkin values for the four dimensions exceeded the recommended value of 0.6 (Pallant, 2001). The Bartlett's Test of Sphericity (Pallant, 2001) for the dimensions also reached statistical significance, supporting the factorability of the correlation matrix.

Four criteria were used to extract factors. Firstly, the criterion of simple structure was employed in all factor analyses. This means that the items that loaded on more than one factor were omitted to achieve a purer measure of the different dimensions and sub dimensions of teacher professionalism. Secondly, items were evaluated for conceptual clarity. This means that those items which loaded on a factor with a value greater than or equal to 0.40 and those, which contributed logically to the meaning on the factor were considered significant for the factor. Thirdly, items were eliminated if they reduced substantially the internal consistency of the items in the factor as measured by Cronbach's Alpha. Fourthly, Kaiser's (cited in Bryman \& Cramer, 2001) criteria and Cattell's (cited in Bryman \& Cramer, 2001) Scree Test method was used to decide the number of factors that were to be retained. Only those factors were retained which had eigenvalue greater than one or which lay before the point at which the eigenvalues seem to level off.

\section{Results of the survey research}

Analysis of teacher efficacy scale

Using the four criteria, it was decided to retain two factors for further investigation. The two-factor solution explained $42.79 \%$ of the variance, with Factor 1 contributing $32.36 \%$ and Factor 2 contributing $10.43 \%$.

Factor 1 was titled 'Belief that all aspects of work and change can be achieved' and Factor 2 was titled 'Belief in executing responsibilities for achievement'. Table 1 shows these factors with their factor loadings. 
Table 1. Item loadings in the factor analysis for teacher efficacy scale

\begin{tabular}{llll}
\hline Factors & Loading & Mean & SD \\
\hline Factor 1. Belief that all aspects of work and change can be achieved & & & \\
Eff 4: Implementing effective teaching methods to help students & 0.52 & 4.26 & 0.83 \\
Eff 5: Getting good results with the difficult students & 0.65 & 3.90 & 0.95 \\
Eff1 1: Bringing about change in the school & 0.69 & 4.18 & 0.84 \\
Eff12: Dealing with almost any learning problem & 0.70 & 4.01 & 0.93 \\
Eff13: Teaching other teachers about innovative teaching methods & 0.84 & 3.97 & 0.89 \\
Eff14: Influencing other teachers in the school to improve their teaching & 0.78 & 3.94 & 0.86 \\
Factor 2. Belief in executing responsibilities for achievement & & & \\
Eff 1: Getting through to the most difficult students & 0.45 & 4.36 & 0.63 \\
Eff 2: Applying effective classroom management strategies & 0.44 & 4.40 & 0.62 \\
Eff 6: Learning by working with the students & 0.62 & 4.42 & 0.59 \\
Eff 7: Helping each child to learn & 0.67 & 4.61 & 0.62 \\
Eff 8: Helping every child to make academic progress & 0.66 & 4.68 & 0.52 \\
Eff10: Successfully carrying out the responsibilities & 0.70 & 4.61 & 0.53 \\
\hline
\end{tabular}

This analysis implies that the teachers recognized two factors as underlying dimensions of teacher efficacy. The loading column in Table 1 shows that the items correlate strongly (greater than 0.4 ) with the factors. The high mean scores and the low SD values, in Table 1, show that most of the teachers have scored high and have agreed with these items. Factor 1 produced an alpha of 0.82 , which was acceptable for an attitude test (Burns, 2000). The reliability test of Factor 2 produced an alpha of 0.73 , which was just acceptable.

The first factor illustrated teachers' beliefs in their abilities to teach effectively and to achieve good results even with the most difficult students. In addition to demonstrating high classroom teaching efficacy, these teachers believed that they could bring about positive change in their school. They felt confident that they had the skills and abilities to train other teachers in their school.

Mean scores for all the items in Factor 2 (see Table 1) are very high. This brings to light a strong construct in teachers' minds about believing in their own selves to remain committed in executing teaching and other responsibilities. The findings suggest that the teachers believed that successful execution of administrative and teaching responsibilities, such as helping children learn, was important for enhancing their own professionalism.

\section{Analysis of the teacher practice scale}

Using the four criteria two factors were retained for further investigation. The two factor solution explained $49.73 \%$ of the variance, with Factor 1 contributing $37.47 \%$ and Factor 2 contributing $12.26 \%$.

Looking at the items of the two factors, the first was named, 'Executing responsibilities with commitment' and the second as 'Applying professional knowledge for student learning'. Table 2 shows the factor item loadings, the item mean and the item standard deviation of all the items in the two factors. 
Table 2. Item loadings in the factor analysis of teacher practice scale

\begin{tabular}{llll}
\hline Factors & Loadings & Mean & SD \\
\hline Factor 1. Executing responsibilities with commitment & & & \\
Tp1. Listen to the students and offer advice & 0.75 & 4.62 & 0.56 \\
Tp2: Maintain friendly relationship with the students & 0.69 & 4.58 & 0.57 \\
Tp12. Regard teaching as a moral responsibility & 0.67 & 4.72 & 0.62 \\
Tp13. Consider it their duty to be accountable for their actions & 0.74 & 4.67 & 0.54 \\
Tp15. Consider it their moral responsibility to teach in ways & 0.74 & 4.61 & 0.56 \\
$\quad$ which facilitates students' learning & & & \\
Factor 2. Applying professional knowledge for student learning. & & & \\
Tp3. Have a strong knowledge base & 0.59 & 4.42 & 0.66 \\
Tp5. Use a variety of teaching methods & 0.80 & 4.31 & 0.79 \\
Tp6. Use appropriate student evaluation methods & 0.60 & 4.39 & 0.65 \\
Tp11. Implement new teaching approaches in their classes & 0.62 & 4.30 & 0.80 \\
Tp14. Take time out of their schedule to be there for the & 0.50 & 4.24 & 0.76 \\
$\quad$ students & & & \\
\hline
\end{tabular}

Table 2 shows that the teachers recognized two dimensions of teacher practice as significant in regard to enhancing their professionalism. It can be observed that the item loadings are high, with the lowest being 0.50. Looking at the high mean scores and low SD values, it can also be concluded that most of the teachers have scored high and have agreed with the items in the two factor scales. Factor 1 produced an alpha of 0.79, which was acceptable for an attitude test (Burns, 2000). The reliability test of Factor 2 produced an alpha of 0.75 , which was also just acceptable.

The high factor loadings of the items in Factor 1 illustrate that teachers' attitude towards 'Executing responsibilities with commitment' is an important dimension of teacher professional practice. The inclusion of items $\mathrm{Tp} 1$ and $\mathrm{Tp} 2$ in Factor 1 is interesting because it reflects teachers' commitment not only to work responsibly, but also to relate with the children in a friendly manner and consider their wishes. The other interpretation for this could be that the teachers considered it part of their moral responsibility to guide children and to maintain good relationships with them. The high mean scores and low SD for the items in Factor 1 show that most of the teachers regarded execution of responsibilities in a moral fashion, as suggested by the items in the factor, important indicators of their professional practice.

Factor 2, 'Applying professional knowledge for student learning', consists of items with high mean score and low SD. This suggests that teachers considered application of knowledge and experimentation with different teaching approaches as important aspects of their professional practice. Another important point to notice in Factor 2 is that the loading for Item Tp5 is higher than the loading for the other items. This appears to suggest that the use of innovative teaching methods is very significant for these teachers and a major contributor in developing their professionalism. 


\section{Analysis of the teacher collaboration scale}

Based on the four criteria, two factors were selected for further investigation. The two factor solution explained $51.80 \%$ of the variance, with Factor 1 contributing $40.68 \%$ and Factor 2 contributing $11.11 \%$.

Considering the items of the factors, Factor 1 was named 'Collaborating for planning and teaching' and Factor 2 was named 'Administrative collective work'. The two factors, along with their factor loadings, mean values and standard deviation are given in Table 3.

From Table 3, it may be deduced that there are two underlying dimensions of teacher collaboration. Though there is variation in the mean scores of the items in the two factors, the mean scores are still high. This suggests that most of the teachers have agreed with the items. With a standard deviation greater than one for most of the items, it may be deduced that the scores are not clustered around the mean to the degree that they were in the teacher practice and teacher efficacy scale. Factor 1 produced an alpha of 0.86, which was acceptable for an attitude test (Burns, 2000). The reliability test of Factor 2 produced an alpha of 0.84 , which was also acceptable.

Factor 1 comprises items which indicate teachers' perceptions about the different ways in which they collaborate for teaching and for planning to enhance their professionalism. Except for items TC4 and TC5, the SD values for the items is greater than one. This means that while most of the teachers agreed with the items in the scale, there are also those teachers who have disagreed with the items in the scale.

The four items in Factor 2 have high inter-item correlation and have produced a high Alpha score, which verifies that all the items focus on administrative collective work. Interestingly in this case too, the item mean values are high and the SD values

Table 3. Item loadings in the factor analysis of teacher collaboration scale

\begin{tabular}{llll}
\hline Factors & Loadings & MEAN & SD \\
\hline $\begin{array}{l}\text { Factor 1. Collaborating for planning and teaching } \\
\text { TC 1. Having discussions on teaching/learning issues with the other }\end{array}$ & 0.68 & 4.10 & 1.01 \\
& & & \\
teachers & 0.59 & 3.16 & 1.24 \\
TC 2. Teaching other teachers about innovative teaching techniques & 0.71 & 3.60 & 1.22 \\
TC 3. Inviting other teachers to help teach in their classes & 0.65 & 4.09 & 0.99 \\
TC 4. Receiving feedback on their performances & 0.50 & 4.23 & 0.78 \\
TC 5. Learning by observing other teachers classes & 0.67 & 3.75 & 1.14 \\
TC 7. Reflecting on their teaching with the other teachers & 0.76 & 3.86 & 1.03 \\
TC 8. Coordinating with the other teachers to plan effective lessons & & & \\
TC 9. Planning instructional programmes with the other teachers & 0.76 & 3.73 & 1.12 \\
TC10. Working together to plan school activities & 0.62 & 3.74 & 1.11 \\
Factor 2. Administrative collective work & & & \\
TC1 1. Using staff meetings to involve teachers in solving problems & 0.84 & 3.92 & 1.09 \\
TC12. Teachers discussing different issues during the staff meetings & 0.86 & 3.90 & 1.07 \\
TC14. Experienced teachers helping the new teachers & 0.62 & 4.27 & 0.81 \\
TC15. Learning new teaching/learning approaches during the staff & 0.82 & 4.06 & 1.01 \\
$\quad$ meetings & & & \\
\hline
\end{tabular}


demonstrate a spread of responses. Therefore, it can be deduced that a larger group of teachers are involved in administrative collective work in the manner demonstrated by the items in the scale.

\section{The analysis of teacher leadership scale}

Three factors were retained for further investigation. The three-factor solution explained $54.48 \%$ of the variance, with Factor 1 contributing $31.24 \%$, Factor 2 contributing $13.55 \%$ and the third factor contributing $9.69 \%$ of the variance.

Considering the items, Factor 1 was titled, 'School leadership', while Factor 2 and Factor 3 were called 'Classroom leadership' and 'Centralized leadership' respectively. The three factors along with the inter-item correlation values, the item mean values and the standard deviation are presented in Table 4 .

Table 4 implies that the teachers consider the three factors as the important dimensions of teacher leadership. The items highly correlate with the factor. The mean scores range from 3.10 to 4.43 and the standard deviation greater than 1 for most of the items, indicating that all the teachers have not agreed with the items. The first factor produced an Alpha of 0.79, which was acceptable. The Alpha score for the Factor 2 was 0.59 and Factor 3 produced an Alpha of 0.55. Despite the fact that Factors 2 and 3 produced relatively lower Alpha score, they were retained because of their meaningfulness to the study and also because of high inter-item correlation.

The results of the factor analysis for teacher leadership can be explained in a number of ways. The inter-item correlation shows that both Factor 1 and Factor 2, are important sub-dimensions of teacher leadership. However, they illustrate teacher leadership at different levels. What this could mean is that the teachers considered assuming leadership roles both at the class and the school level important for enhancing their professionalism.

Table 4. Item loadings in the factor analysis for teacher leadership scale

\begin{tabular}{lccc}
\hline Factors & Loading & Mean & SD \\
\hline Factor 1. School leadership (delegated authority and teacher involvement & in decision & making) & \\
TL 6. Given the opportunities to undertake leadership roles & 0.66 & 3.13 & 1.37 \\
TL 7. Given the opportunities to monitor teacher training programmes & 0.66 & 2.96 & 1.36 \\
TL 8. Given the responsibility of planning school activities & 0.76 & 3.56 & 1.24 \\
TL 9. Given the responsibility of mentoring new teachers & 0.78 & 3.10 & 1.30 \\
TL11. Distribution of power throughout the school organization & 0.54 & 3.50 & 1.33 \\
Factor 2. Classroom leadership & & & \\
TL 1. Teachers in control of their classroom affairs & 0.77 & 4.38 & 0.74 \\
TL 2. Authority to choose their teaching methods & 0.71 & 4.43 & 0.71 \\
Factor 3. Centralised leadership & & & \\
TL12. Location of power at the top & 0.62 & 4.17 & 1.06 \\
TL13. Decision making taking the form of a centralised approach & 0.65 & 3.97 & 1.11 \\
\hline
\end{tabular}


Another interesting finding is the variation in the teachers' responses. The mean values for the items in Factor 1 are relatively lower than the items in the other two factors, and the SD values are relatively higher. It may be deduced from these findings that one group of teachers were given opportunities to experience leadership roles at the school level in the ways indicated by the items in the factor, while the other group were not provided with opportunities to undertake such leadership.

Looking the mean and SD values of Factors 1 and 2, it can be inferred that the teachers may not enjoy as many opportunities to undertake school leadership tasks as they do to assume classroom leadership roles.

Even though Factor 3 had produced a very low Alpha Score, it was retained to indicate the fact that the government schools in Karachi worked under the centralized management at the time this research was conducted. Interestingly the teachers have indicated in Item 11, that within the overall centralized set up of the schools where reforms have been initiated, teachers are now being provided with the opportunities to make their classroom decisions and undertake some leadership roles.

\section{Discussion about the four dimensions}

The analysis has shown that the teachers in government primary schools, where reforms had been initiated, are professionals to the extent that the different dimensions of teacher efficacy, teacher practice, teacher collaboration and teacher leadership have been revealed. In general terms, the dimensions hypothesized from the general literature on teacher professionalism and reform initiatives in Karachi have been contextualized to understand teachers' perceptions of their professionalism.

The reliability of these dimensions was also confirmed when the total sample of 450 teachers was split into half on the basis of median scores of the teachers' age, educational qualification, experience and school size and the same procedures for factors analysis were applied to both halves (consisting of approximately more than 200 teachers in each half). The factors obtained from smaller samples were exactly the same as the factors of the total sample. These findings point to the stability of the factors obtained for the four dimensions of professionalism.

The government primary school teachers have identified two important dimensions of teacher efficacy, which they believe are important for enhancing teacher professionalism. These are:

1. Belief that all aspects of work and change can be achieved.

2. Belief in executing responsibilities for achievement.

The teachers appeared to think about professionalism in terms of their capacity to achieve success in different types of work, such as dealing with learning problems and getting good results with the difficult students. Being a professional teacher meant that by working in this way a teacher could influence other teachers in the school and could bring about change in the school. This sub-dimension is very 
similar to Beck and Murphy's (1996) two core components of teacher efficacy. The first is the belief that one is capable of doing her or his work effectively. The second is the notion that one can make a difference in some larger sense; that an individual's work and decisions can help to bring about positive change in a system (Beck \& Murphy, 1996).

The teachers in this research also believed that a professional teacher should be able to execute different responsibilities successfully, whether it was helping children make academic progress or it was carrying out the other school responsibilities successfully. Tschannen-Moran et al. (1998) give several examples where teacher efficacy has been linked to the level of professional commitment for both in-service elementary, middle school teachers and pre-service teachers.

Concerning the second dimension of teacher professionalism, the teachers have indicated two important dimensions of teacher practice that are important for enhancing their professionalism. These dimensions are:

1. Executing commitment and responsibilities.

2. Applying professional knowledge for student learning.

The government primary school teachers have indicated their professionalism in terms of being responsible for and committed to their profession. The teachers showed their commitment by indicating that they worked responsibly and they taught in ways which facilitated students' learning. These teachers used a variety of teaching methods, evaluated students' performances and implemented new teaching approaches in their classes because they wanted to apply their professional knowledge for student learning. Teachers endeavoured to apply professional knowledge and to work responsibly. These findings concur with Slavin's (1991) description of effective teachers, who motivate students to learn, group students for instruction, and assess the students' learning. Eraut (1995) also argues that being a professional practitioner implies a moral commitment to serve the interest of students. The standards of professional teaching practice set by the National Board for Professional Teaching Standards (Kelly, 2000), also recognize teacher commitment, strong knowledge base, the use of different teaching methods and selfevaluation as important indicators of professional teacher practice. The teachers in the survey have also indicated these aspects of professional teaching practice as important indicators of their professionalism.

The analysis also illustrates teacher collaboration as an important dimension of teacher professionalism. The two dimensions of teacher collaboration, which the government primary school teachers have indicated as important for sustaining professional practice in their schools are as follows:

1. Collaborating for planning and teaching.

2. Administrative collective work.

Holding discussions with the other teachers on teaching issues, reflecting on their teaching with the other teachers and coordinating with teachers to plan effective lessons have been indicated by the teachers as some of the important aspects of their 
collaboration. In short, teachers collaborated for planning and teaching in different ways. In addition, the data suggest that the school administration provided teachers with the opportunities to be involved in administrative collective work in order to discuss different teaching problems or to learn about new teaching and learning approaches during the staff meetings.

Work of several educators (Purkey \& Smith, 1982; Reynolds, 1988; Rosenholtz, 1989; Mortimer et al., 1994; Hopkins, 1996; Hargreaves, 1997; Day, 1999) indicates collaboration as an essential ingredient of teacher development and thus school improvement.

The teachers have also indicated that their professionalism involves leading both within and outside their classrooms. They have highlighted the following three dimensions as important for promoting teacher professionalism.

1. School leadership (delegated authority).

2. Centralized leadership.

3. Classroom leadership.

The teachers indicated that they undertook leadership roles, which were related to school tasks such as being the subject coordinator or mentor for new teachers or the project in-charge. They also had the authority to choose their teaching methods and to be in control of their classroom affairs. Teachers believe that the delegation of authority and classroom authority are indicators of their professionalism.

These dimensions of teacher leadership agree with the characteristics of teacher leaders identified as important by educators such as Moller et al. (2000), Cooper and Conley (1991) and Macpherson et al. (1999), who assert that teacher professionalism greatly depends on such factors as level of discretion, control over work, ability to mobilize resources and inclusion in school decisions.

\section{Conclusion}

The results of this study illustrate that teachers in government primary schools, where reforms have been initiated, perceive themselves as professionals capable of leading students successfully and improving the teaching scenario in government primary schools in Karachi. These findings are important for a number of reasons and have implications for future teacher development initiatives in Pakistan.

The findings of the factor analysis study reported here need to be placed in the context of schooling and teacher development in Pakistan. In other words the specific scales that have been developed and their meanings need to be elaborated in terms of the system and life worlds of teachers in these schools. In order to do this, the various scales could be used as the basis of case study enquiries in various schools in Karachi.

These findings are in contrast with the way teachers in the government primary schools are generally described as having a detached and non-committal attitude and rely on teacher talk methods to fill students minds with different facts (IDCA, Ministry of Education, Pakistan, 1986; Hoodbhoy, 1998; The Ministry of Education, 1998). The empirical data suggest that this generalization about the 
teachers does not appear to apply to the teachers in the government primary schools where reforms have been initiated. Therefore, these findings are also significant for various pragmatic reasons. For example, they could well be the basis of planning and implementing various professional development activities for Pakistan teachers to ensure that reform initiatives to improve teaching in Pakistan are successful. The findings highlight issues that are significant for teachers-the starting point for successful reform initiatives.

\section{References}

Bandura, A. (1982) Self-efficacy mechanism in human agency, American Psychologist, 37, $122-147$.

Bandura, A. (1995) Exercise of personal and collective efficacy in changing societies, in: A. Bandura (Ed.) Self-efficacy in changing societies (Cambridge, Cambridge University), $1-45$.

Beck, L. G. \& Murphy, J. (1996) The four imperatives of a successful school (Thousand Oaks, CA, Corwin).

Bell, J. (1993) Doing your research project (Buckingham, Open University).

Bhindi, N. \& Duignan, P. (1997) Leadership for a new century: authenticity, intentionally, spirituality and sensibility, Educational Management and Administration, 25(2), 117-130.

Bouma, G. D. (1996) The research process (Melbourne, Oxford).

Broudy, H. S. (1988) The uses of schooling (New York, Routledge).

Bryman, A. \& Cramer, D. (2001) Quantitative data analysis with SPSS Release 10 for Windows (East Sussex, Routledge).

Bureau of Curriculum and Extension Wing (1997) SPEDP-II: school development component (Jamshoro, Bureau of Curriculum and Extension Wing).

Burns, R. B. (2000) Introduction to research methods (Frenchs Forest, Pearson Education).

Campbell, E. (2000) Professional ethics in teaching: towards the development of a code of practice, Cambridge fournal of Education, 30(2), 203-221.

Chester, M. D. \& Beaudin, B. Q. (1996) Efficacy beliefs of newly hired teachers in urban schools, American Educational Research fournal, 33(1), 233-257.

Cohen, L., Manion, L. \& Morrison, K. (2000) Research methods in education (London, Routledge Falmer).

Cole, P. G. \& Chan, L. K.S. (1994) Teaching principles and practice (New York, Prentice Hall).

Cooper, B. S. \& Conley, S. C. (1991) From blame to empowerment: critical issues in the teacher work environment, in: S. C. Conley \& B. S. Cooper (Eds) The school as a work environment: implications for reform (Boston, MA, Allyn \& Bacon), 2-16.

Darling-Hammond, L. (1995) Changing conceptions of teaching and teacher development, Teacher Education Quarterly, 22(4), 9-26.

Day, C. (1999) Developing teachers: the challenges of lifelong learning (London, Falmer).

Duignan, P. A. (1996) Leadership in learning communities (Sydney, Australian Catholic University).

Elliott, R. (2000) Professional development with eyes wide shut, paper presented at Chi Nan University, Taiwan, May.

Eraut, M. (1994) Developing professional knowledge and competence (London, Falmer Press).

Eraut, M. (1995) Developing a professional knowledge within a client-centered orientation, in: T. R. Guskey \& M. Huberman (Eds) Professional development in education (New York, Teachers College), 227-252.

Farr, J. L. \& Middlebrooks, C. L. (1990) Enhancing motivation to participate in professional development, in: S. L. Willis \& S. S. Dubin (Eds) Maintaining professional competence: approaches to career enhancement, vitality, and success throughout a work life (San Francisco, CA, Jossey-Bass), 195-213. 
Fullan, M. G. (1982) The meaning of educational change (New York, Teachers College).

Fullan, M. (1997) The complexity of school change, in: M. Fullan (Ed.) The challenge of school change (Cheltenham, Hawker Brownlow), 27-45.

Gay, L. R. (1996) Educational research (New Jersey, Merrill).

Gibson, S. \& Dembo, M. (1984) Teacher efficacy: a construct validation, fournal of Educational Psychology, 76(4), 569-582.

Guskey, T. R. \& Huberman, M. (Eds) (1995) Professional development in education (New York, Teachers College).

Guskey, T. R. \& Passaro, P. D. (1994) Teacher efficacy: a study of construct dimensions, American Educational Research fournal, 31(3), 627-643.

Hargreaves, A. (1997) The four ages of professionalism and professional learning, UNICORN, 23(2), 86-108.

Hargreaves, A. \& Fullan, M. G. (1992) Introduction, in: A. Hargreaves \& M. G. Fullan (Eds) Understanding teacher development (New York, Cassell), 1-17.

Hargreaves, A. \& Fullan, M. G. (1998) What's worth fighting for out there? (New York, Teachers College).

Hart, A. W. (1995) Reconceiving school leadership: emergent views, The Elementary School fournal, 96(1), 9-27.

Hoodbhoy, P. (Ed.) (1998) Education and the state: fifty years of Pakistan (Karachi, Oxford University).

Hopkins, D. (1996) Towards a theory of school improvement, in: D. Gray, D. Reynolds \& C. FitzGibbon (Eds) Merging traditions: the future of research on school effectiveness and school improvement (London, Cassell), 30-35.

Hoy, W. K., Tarter, C. J. \& Kottkamp, R. B. (1991) Open schools/healthy schools (Newbury Park, Sage).

Hoy, W. K. \& Woolfolk, A. E. (1993) Teachers' sense of efficacy and the organizational health of schools, The Elementary School fournal, 93(4), 355-372.

IDCA (Agency for International Development), Ministry of Education (1986) Primary education in Pakistan: an analysis and assessment of Pakistan's present primary education system with recommendations for its further development (Arlington, VA, Development Associates).

Ingvarson, L. (1997) Teachers matter most, UNICORN, 23(3), 31-35.

Internet Wing Ministry of Information, Government of Pakistan (2000) Pakistan basic facts. Available online at: http://www.pak.gov.pk/public/govt/basicfacts.html (accessed 5 April 2000).

Jalil, N. (1998) Pakistan's education: the first decade, in: P. Hoodbhoy (Ed.) Education and the state: fifty years of Pakistan (Karachi, Oxford University), 23-42.

Katzenmeyer, M. \& Moller, G. (1996) Awakening the sleeping giant (Thousand Oaks, CA, Corwin).

Kelly, J. A. (2000) Advanced professional certification for teachers: catalyst for broad band-width educational reform, UNICORN, 26(1), 8-21.

Klecker, B. \& Loadman, W. E. (1998) A study of teacher empowerment in 180 restructuring schools: leadership implications, paper presented to the Annual Meeting of the American Association of Colleges for Teacher Education, Chicago, IL.

Lieberman, A. (1992) Teachers, their world and their work: implications for school improvement (New York, Teachers College).

Macpherson, I., Aspland, T., Brooker, R. \& Elliott, R. (1999) Places and spaces for teachers in curriculum leadership (Sydney, Australian Curriculum Studies Association).

McLaughlin, M. W. \& Oberman, I. (Eds) (1996) Teacher learning: new policies, new practices (New York, Teachers College).

Moller, G., Pankake, A. M., Huffman, J. B., Hipp, K. A., Cowan, D. \& Olivier, D. (2000) Teacher leadership: a product of supportive and shared leadership within professional learning communities, paper presented to the Annual Meeting of the American Educational Research Association, New Orleans, April. 
Mortimer, P., Sammons, P., Stoll, L., Lewis, D. \& Cob, R. (1994) Key factors for effective junior schooling, in: A. Pollard \& J. Bourne (Eds) Teaching and learning in the primary school (London, Routledge).

Pallant, J. (2001) SPSS survival manual (Crows Nest, Allen \& Unwin).

Purkey, W. \& Smith, M. S. (1982) Synthesis of research on effective schools, Educational Leadership, 40(3), 64-69.

Reaves, C. A. \& Griffith, H. (1992) Restructuring schools: theory and practice (Lancaster, Technomic).

Reynolds, D. (1988) The consultant sociologist: a method for linking sociology of education and teachers, in: P. Woods \& A. Pollard (Eds) Sociology and teaching: a new challenge for the sociology of education (Beckenham, Croom Helm), 158-175.

Riggs, I. \& Enochs, L. (1990) Toward the development of an elementary teacher's science teaching efficacy belief instrument, Science Education, 74(6), 625-638.

Rizvi, M. (1999) A study of attitudes towards teacher effectiveness amongst the selected educators in Karachi, Pakistan unpublished master's thesis, Karachi University, Karachi.

Rosenholtz, S. (1989) Teachers' workplace: the social organisation of schools (New York, Longman).

Scribener, J. P. (1998) Teacher efficacy and teacher professional learning: what school leaders should know, paper presented to the Annual Convention of the University Council for Educational Administration, St Louis.

Sergiovanni, T. J. (1994) Building community schools (San Francisco, CA, Jossey-Bass).

Sergiovanni, T. J. (1998) Organization, market and community as strategies for change: what works best for deep changes in schools, in: A. Hargreaves, A. Lieberman, M. Fullan \& D. Hopkins (Eds) International handbook of educational change (London, Kluwer Academic).

Shacklock, G. (1994) Professionalism and changing conceptions of teachers' work, Teaching and Teachers' Work, 2(1), 1-12.

Shaikh, M. A. (1997 September 19) Education for none, Dawn, p. 6.

Sindh Education Foundation (1998) Adopt a school program (Karachi, Sindh Education Foundation).

Slavin, R. E. (1991) Educational psychology (New Jersey, Prentice-Hall).

Smylie, M. A. (1988) The enhancement function of staff development: organizational and psychological antecedents to individual teacher change, American Educational Research fournal, 25(1), 1-30.

Smylie, M. A. (1995) New perspectives on teacher leadership, The Elementary School fournal, 96(1), $1-7$.

Teachers' Resource Centre (1999) The thirteenth annual report (Karachi, Teachers' Resource Centre).

The Book Group (1996) Twenty-seventh quarterly progress report (Karachi, The Book Group).

The Ministry of Education (1998) National education policy 1998-2010 (Islamabad, Government of Pakistan).

Tschannen-Moran, M., Woolfolk, A. \& Hoy, W. K. (1998) Teacher efficacy: its meaning and measure, Review of Educational Research, 68(2), 202-248.

UNESCO (1994) Initial and continuing education of teachers in Pakistan (Geneva, Division of Higher Education).

Wallace, J. \& Hellen, W. (1995) The changing world of school leadership: working in a professional organization today, The Practicing Administrator, 17(1), 14-17.

Warwick, D. P. \& Fernando, R. (1995) Hope or despair? Learning in Pakistan's primary schools (Westport, Praeger).

Webb, R. \& Ashton, P. T. (1987) Teachers' motivation and the conditions of teaching: a call for ecological reform, in: S. Walker \& L. Barton (Eds) Changing policies, changing teachers: new directions for schooling (Philadelphia, Open University), 22-40.

Whitbey, G. (1995) Challenging the existing mindset-organizational structures for the schools of the future (Sydney, Australian Catholic University). 
Willis, S. L. \& Tosti-Vasey, J. L. (1990) How adult development, intelligence and motivation affect competence, in: S. L. Willis \& S. S. Dubin (Eds) Maintaining professional competence: approaches to career enhancement, vitality and success throughout a work life (San Francisco, CA, Jossey-Bass), 64-84.

Wilson, S. \& Cameron, R. (1996) Student teacher perceptions of effective teaching: a developmental perspective, fournal of Education for Teaching, 22(2), 181-193. 